\title{
PERFORMANCE OF SEVEN NEW CYTOPLASMIC MALE-STERILE SUNFLOWER LINES FROM INDUCED MUTATION AND A NATIVE AMERICAN VARIETY
}

\author{
Jan, C.C. ${ }^{*}$, Miller, J.F., Vick, B.A. and Seiler, G.J.
}

Northern Crop Science Laboratory, USDA-ARS, Box 5677, Fargo, ND 58105, USA

Received: September 10, 2005

Accepted: March 25, 2006

\section{SUMMARY}

Six mutant cms HA 89 lines, cms PI 432513 from a native American variety, and the French cms PET1 in an HA 89 background were compared in replicated yield trials at Fargo, ND and Casselton, ND in 2003 and 2004. Data collected included lodging \%, days to flower, days to maturity, plant height, head diameter, yield, test weight, seed moisture content, and oil concentration. Differences among the eight cms lines for lodging, days to maturity, head diameter, yield, and oil \% were not significant. The other traits were significant among lines, but most of them were not significantly different from $\mathrm{cms}$ HA 89, with a maximum days to flower of 2 days later, plant height up to $9 \mathrm{~cm}$ taller, test weight from $2.8 \mathrm{~kg} / \mathrm{hl}$ less to $1.2 \mathrm{~kg} / \mathrm{hl}$ more, and 1000 seed weight from $2.6 \mathrm{~g}$ less to $6.0 \mathrm{~g}$ more. The six new $\mathrm{cms}$ lines are therefore considered agronomically equal to the French $c m s$ PET $1 . F_{1}$ hybrids of these eight $c m s$ lines pollinated with oilseed restorer, RHA 274, and confectionery restorer, RHA 294, were also evaluated in separate yield trials. A similar interpretation for the parental $\mathrm{cms}$ lines can be made for the hybrids. The use of one oilseed restorer RHA 274, and one confectionery restorer RHA 294 contributed to the significant differences in days to flowering, plant height, test weight, 1000 seed weight, and oil \%. However, the $\mathrm{F}_{1}$ deviations involving the new $\mathrm{cms}$ lines from cms HA 89 are within the acceptable levels of most breeding programs. Based on our results, the seven new cms appear equal to, if not better than, the French cms PET1 cytoplasm for hybrid sunflower production. Since new restoration lines will not be required, the new $\mathrm{cms}$ lines could be quickly utilized by the sunflower industry.

Key words: sunflower, Helianthus annuus L., cytoplasmic male sterility, fertility restoration

* Corresponding author: Phone: +1 701239 1319, Fax: +1 701239 1346,

e-mail: janc@fargo.ars.usda.gov 


\section{INTRODUCTION}

World-wide hybrid sunflower production has been based on one cytoplasm, the French cms PET1 derived from Helianthus petiolaris, and a few restoration genes for nearly 30 years (Leclerq, 1969). The need for genetic diversity of both cytoplasmic and nuclear genes has been recognized, and new cms sources discovered (Serieys, 2002). However, there are no reports of utilization of these new $\mathrm{cms}$ sources for commercial hybrid production. This reluctance is assumably due to the lack of superior cms -restorer combinations, as well as the time-consuming process of converting both $\mathrm{cms}$ and restoration genes into inbred lines.

Jan and Rutger (1988) produced 22 cytoplasmic male-sterile mutants by treating maintainer line HA 89 with mitomycin-C and streptomycin. Male fertility of all mutant $c m s$ HA 89 lines and cms HA 89 was completely restored by RHA 266, RHA 274, RHA 280, and RHA 296. More recently, a native American Indian variety, PI 432513, was shown to possess male-sterile cytoplasm and a corresponding fertility restoration gene (Jan and Vick, 1997, 1998). Cms PI 432513 also was completely restored by six $H$. petiolaris restoration lines, RHA 265, RHA 266, RHA 274, RHA 294, RHA 296, and RHA 801. This uniform and complete fertility restoration of the 22 mutant cms HA 89 lines and cms PI 432513 suggested that $\mathrm{Rf}_{1}$ was a factor in their restoration. Since the $\mathrm{Rf}_{1}$ restoration gene is already in commercial restorer lines, hybrid breeding programs could focus primarily on $\mathrm{cms}$ line development.

The objectives of this study were to characterize six selected mutant cms HA 89 lines and $\mathrm{cms}$ PI 432513, and compare them with the French cms HA 89.

\section{MATERIALS AND METHODS}

Six mutant cms HA 89 lines, selected as sectorial $\mathrm{cms}$ on treated HA 89 plants and maintained by pollinating with HA 89 , and $\mathrm{cms}$ PI 432513 , with the pedigree of cms PI 432513/HA $89 * 4$ were used as new cms sources. Designations of these six mutant cms HA 89 lines are cms 45-1, cms 139-1, cms 491-1, cms 515-1, cms 5551 , and $\mathrm{cms} 3149$. To avoid unequal competition between $\mathrm{cms}$ parental lines and the $\mathrm{F}_{1}$ hybrids, two separate yield trials were established.

One trial included the six mutant cms HA 89 lines, cms PI 432513, and the French $c m s$ PET 1 in an HA 89 background. The second trial included the $\mathrm{F}_{1}$ progenies of these eight $\mathrm{cms}$ lines pollinated with oilseed restorer, RHA 274, and confectionery restorer, RHA 294. It was conducted in 2002 in the field at Fargo, ND.

A randomized complete block design with three replications was used for both trials. Each entry was planted in a 16-foot row, at Fargo and Casselton, North Dakota, in the summers of 2003 and 2004. The following data were collected: lodging \%, days to flower, days to maturity, plant height, head diameter, yield, test weight, seed moisture content, and oil concentration. Data were processed by the analysis of variance (ANOVA). 


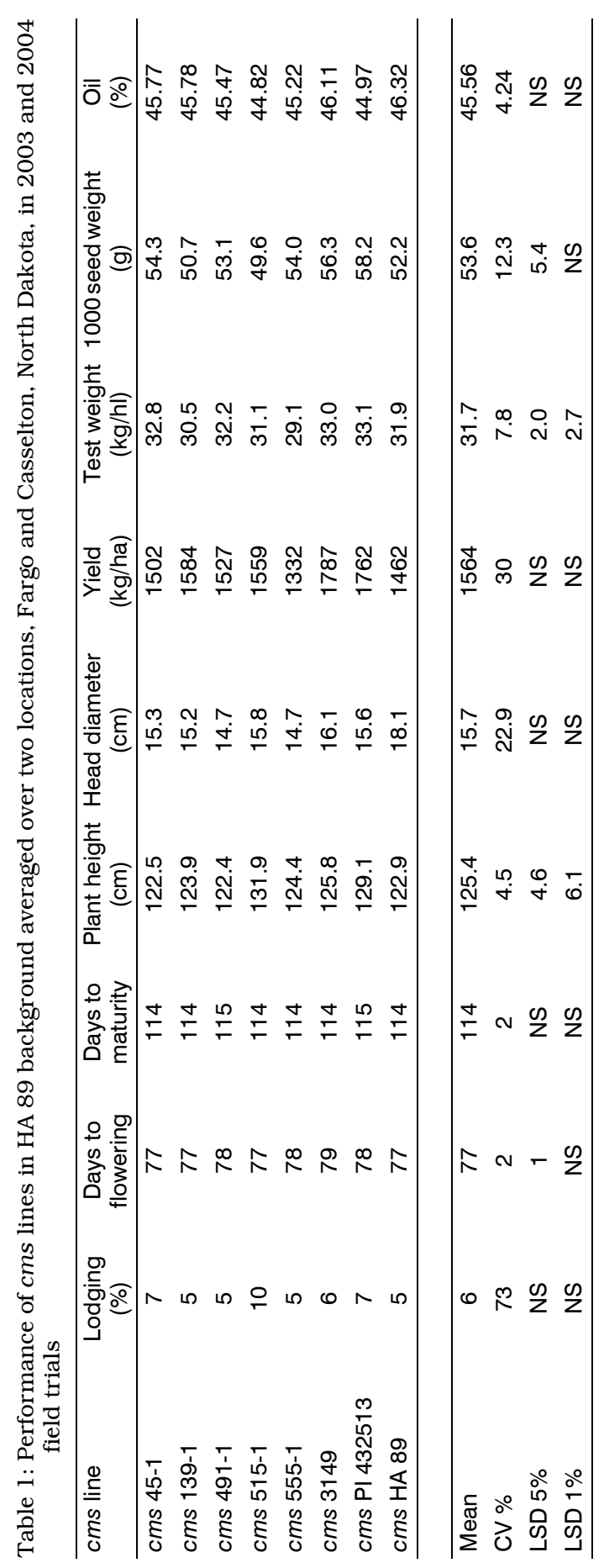




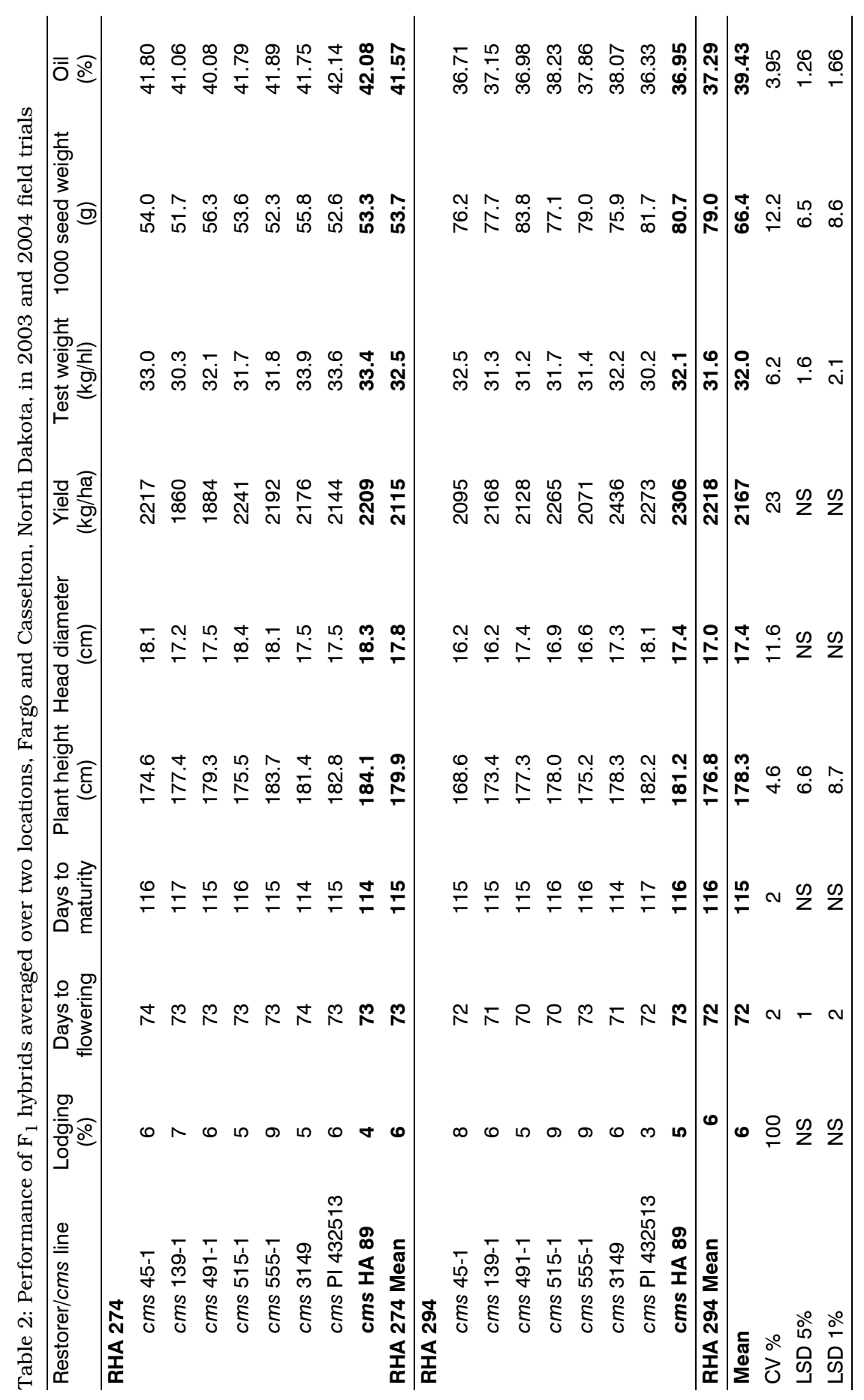




\section{RESULTS AND DISCUSSION}

Since the location $\times$ entry $\times$ year interaction was not significant for yield and other traits, the data were combined for the two locations and two years for analysis. No significant differences (5\%) were detected among the eight $\mathrm{cms}$ lines for lodging, days to maturity, head diameter, yield, and oil \% (Table 1). Days to flowering and 1000-seed weight were significant at 5\%, and plant height and test weight were significant at $1 \%$. However, in most cases difference between the seven lines and the French cms HA 89 were not significant, with a maximum days to flower of 2 days later, plant height up to $9 \mathrm{~cm}$ taller, test weight from $2.8 \mathrm{~kg} / \mathrm{hl}$ less to $1.2 \mathrm{~kg} / \mathrm{hl}$ more, and 1000 seed weight from $2.6 \mathrm{~g}$ less to $6.0 \mathrm{~g}$ more. Therefore, the six new cms lines appeared to be agronomically equal to the French $\mathrm{cms}$ PET1.

The performance of the hybrids was similar to that of the parental $\mathrm{cms}$ lines. Again, lodging \%, days to maturity, head diameter, and yield were non-significant, and the other five characters were significant at $1 \%$ (Table 2). However, a large portion of this significance appeared to be due to the differences between the restorer lines. RHA 274 is an oilseeds restorer, with high oil \%, which resulted in much higher oil \% in its hybrids than that from crosses with the confectionery restorer RHA 294, which is low in oil content. The cms HA 89 crosses in respective groups differed up to three days in days to flowering, plant height by up to $12.6 \mathrm{~cm}$, test weight by up to $3.1 \mathrm{~kg} / \mathrm{hl}, 1000$ seed weight by up to $4.8 \mathrm{~g}$, and oil \% by up to $2 \%$. The $\mathrm{F}_{1}$ deviations involving the new $\mathrm{cms}$ lines from $\mathrm{cms}$ HA 89 are within acceptable levels of most breeding programs.

Based on our results, the seven new $\mathrm{cms}$ sources appear to be equal, if not better than the French $\mathrm{cms}$ PET1 cytoplasm for hybrid sunflower production. The new cms lines are in $H$. annuus cytoplasm, but likely carry the same male sterility gene as that of the classical $H$. petiolaris $\mathrm{cms}$ used in commercial hybrid production. Since new restoration lines will not be required, the new $\mathrm{cms}$ lines can be quickly utilized by the sunflower industry. Seeds of the new cms lines were released to the public in 2005 and are available for breeding.

\section{ACKNOWLEDGMENT}

The skilled technical assistance of Lisa Brown and Dale Rehder is greatly appreciated.

\section{REFERENCES}

Jan, C.C. and J.N. Rutger., 1988. Mitomycin C- and streptomycin-induced male sterility in cultivated sunflower. Crop Sci. 28:792-795.

Jan, C.C. and B.A. Vick., 1997. Cytoplasmic male sterility and fertility restoration in a Helianthus annuus landrace PI 432513. Proc. Sunflower Res. Workshop, Fargo, ND. 910 January, Natl. Sunflower Assoc., Bismarck, ND, USA. pp. 1-2. 
Jan, C.C. and B.A. Vick., 1998. Cytoplasmic male sterility in sunflower landrace PI 432513 and the inheritance of fertility restoration. Proc. Sunflower Res. Workshop, Fargo, ND. 15-16 January, Natl. Sunflower Assoc., Bismarck, ND, USA. pp. 46-49.

Leclerq, P., 1969. Une sterilite cytoplasmique chez le tournesol. Ann. Amelior. Plant. 19:99-106. Serieys, H., 2002. Identification, study and utilization in breeding programs of new $\mathrm{cms}$ sources, in FAO Subnetwork. Proc. 2002 Sunflower Subnetwork Progress Report. 7-9 October 2002. FAO, Rome. Italy.

\title{
CARACTERÍSTICAS DE SIETE LÍNEAS DE ESTERILIDAD CITOPLÁSMICA MASCULINA DE GIRASOL NUEVAS, ENGENDRADAS POR LA MUTACIÓN INDUCIDA Y UNA VARIEDAD AMERICANA NACIONAL
}

\author{
RESUMEN
}

Seis líneas mutadas originarias de cms HA 89, cms PI 432513 originaria de una variedad americana nacional y la línea francesa cms PET1 sobre la base de citoplasma HA 89, fueron comparadas en las pruebas de rendimiento, con repeticiones en Fargo, Dakota del Norte, y Kasellton, Dakota del Norte, a lo largo de los años 2003 y 2004. Los datos recolectados incluyen el porcentaje (\%) de encame, número de días hasta la floración, número de días hasta la madurez, la altura de la planta, diámetro del capítulo, rendimiento, peso voluminoso, el contenido de humedad en el grano y el contenido de aceite. Las diferencias entre ocho líneas cms en el sentido de encame, el número de días hasta la madurez, diámetro del capítulo, rendimiento y el contenido de aceite, no fueron significantes. Las demás diferencias fueron significantes, pero la mayoría de esas diferencias no fueron significantes en relación con cms HA 89, con los valores máximos para el número de días hasta la floración de 2 días más tarde, para la altura de la planta de hasta $9 \mathrm{~cm}$ más alta, para el peso de volumen de $2.8 \mathrm{~kg} / \mathrm{hl}$ menos hasta $1.2 \mathrm{~kg} / \mathrm{hl}$ más y para el peso de 1000 granos de $2.6 \mathrm{~g}$ menos, hasta $6.0 \mathrm{~g}$ de más. Eso significa que las nuevas seis líneas cms pueden ser consideradas como agronómicamente iguales con la línea francesa PET1. Los híbridos $\mathrm{F}_{1}$ de estas ocho líneas cms, polinizadas por el restaurador para el contenido de aceite, RHA 274, y restaurador del tipo de consumo, RHA 294, también fueron calificados en las separadas pruebas de rendimiento. Similares explicaciones, dadas para las líneas parentales $\mathrm{cms}$ pueden ser dadas para los híbridos, también. El uso de un restaurador para el contenido del aceite, RHA 274, y de un restaurador de tipo de consumo, RHA 294, ha contribuido a la presentación de las significativas diferencias en el número de días hasta la floración, altura de la planta, peso de volumen de 1000 granos y el porcentaje del aceite. Pero, la desviación en la generación $F_{1}$ de las nuevas líneas cms en relación hacia la línea cms HA 89, se encontraban dentro de los aceptables niveles para la mayoría de los programas de selección. Sobre la base de nuestros resultados, siete líneas nuevas cms parecen ser iguales, hasta mejores de la citoplasma francesa cms PET1 para la creación de los híbridos de girasol. Como las nuevas líneas restauradoras no van a ser necesarias, es posible incorporar en poco tiempo nuevas líneas $\mathrm{cms}$ en la producción de girasol. 


\title{
PERFORMANCE DE SEPT NOUVELLES LIGNÉES DE TOURNESOL CYTOPLASMIQUE STÉRILES MÂLES CRÉÉES PAR MUTATION INDUITE ET D'UNE VARIÉTÉ DOMESTIQUE AMÉRICAINE
}

\author{
RÉSUMÉ
}

\begin{abstract}
Six lignées cms mutantes HA 89, cms PI 432513 d'une variété américaine indigène et la lignée française cms PET1 sur une base de cytoplasme HA 89 ont été comparées dans des tests de rendement répétés à Fargo, au Dakota du Nord et à Casselton, Dakota du Nord en 2003 et en 2004. Les données recueillies comprennent le \% de verse, le nombre de jours avant la floraison, le nombre de jours avant la maturation, la hauteur de la plante, le diamètre de la tête, le rendement, le poids spécifique, le taux d'humidité dans la graine et la concentration d'huile. Les différences entre les huit lignées $\mathrm{cms}$ pour la verse, le nombre de jours avant la maturité, le diamètre de la tête, le rendement, et le \% d'huile n'étaient pas significatives. Les autres caractéristiques étaient significatives parmi les lignées, mais la plupart d'entre elles ne différaient pas de manière significative de la cms HA 89 , avec un maximum de jours avant la floraison de deux jours plus tard, une hauteur de la plante de $9 \mathrm{~cm}$ plus élevée, un poids spécifique de $2,8 \mathrm{~kg} / \mathrm{hl}$ de moins à $1,2 \mathrm{~kg} / \mathrm{hl}$ de plus et un poids de 1000 graines de 2,6 g de moins à 6,0 g de plus. De l'aspect agronomique, les six nouvelles lignées $\mathrm{cms}$ sont donc considérées égales à la ligne française $\mathrm{cms}$ PET1. Les hybrides $\mathrm{F}_{1}$ de ces huit lignées $\mathrm{cms}$ pollinisées avec un restaurateur oléagineux, RHA 274 et un restaurateur de type comestible RHA 294 ont aussi été évaluées dans les contrôles de rendement distincts. Une interprétation semblable à celle des lignées parentales cms peut aussi être donnée pour les hybrides. L'utilisation d'un restaurateur oléagineux RHA 274 et un restaurateur de type comestible RHA 294 ont contribué à l'apparition de différences importantes pour ce qui est du nombre de jours avant la floraison, la hauteur de la plante, le poids spécifique, le poids de 1000 graines et le pourcentage d'huile. Cependant dans la génération $\mathrm{F}_{1}$, les écarts des nouvelles lignées cms par rapport à la lignée cms HA 89 restent dans les niveaux acceptables de la plupart des programmes de sélection. D’après nos résultats, les sept nouvelles lignées $\mathrm{cms}$ semblent égales, sinon meilleures que le cytoplasme français $\mathrm{cms}$ PET1 pour la production d'hybrides de tournesol. Comme de nouvelles lignées de restauration ne seront pas nécessaires, il est possible d'inclure rapidement les nouvelles lignées cms dans la production du tournesol.
\end{abstract}


